Arch. hist. jap. Vol. 15, n. 2 (September 1958).

P. 197-214.

Anat. Labor. of Prof. H. SETO. Tohoku University, Sendai.

\title{
On the Nerve Supply of Trachea, Bronchus and Lung in Goat.
}

\author{
山羊の父管，気管支及び衎つ神経分布に就て。
}

\author{
Hiroshi OMOTO 於本弘。
}

(Received June 21, 1958.)

The innervation of the lung has been the theme of many histological studies since several decardes ago, and more recently, SUNDER-PLASSMANN, MAGNENAT and some members of this laboratory (HAYASHI, MIZUKOSHI, SAITO, NUMATA and TANAKA) have reported on their researches on the subject with human lung or, from the stand point of comparative anatomy, with the lungs of some animals as materials, throwing much light on the problem.

The present author was also granted the opportunity of pursuing the study on the nerve supply of the trachea, the bronchi and the lungs of goat - an animal never studied in this connection in the past. The materials fixed in $10 \%$ neutral formol solution were cut into $40 \mu$ frozen sections and stained with SETO's impregnation in general use at this laboratory, and the large series of histological preparations thus obtained were carefully examined with special attention to the comparative histological view-point. The following interesting results were obtained.

\section{Individual Findings.}

Prior to my description on the nerve supply of the respiratory apparatus of goat, I will speak a word on its histological structure.

The epithelium of the trachea of goat, as shown in Figs. 7 and 8 , is a 5-6rowed ciliated epithelium, and the basal membrane formed just beneath it, unlike the human basal membrane in this part, is extremely ill developed, being apparently almost absent in some places. The epithelium becomes thinner distalwards and finally at the distal end, becomes a 4-rowed one. The lamina propria mucosae is thicker and more powerfully developed than that in the human trachea and its middle layer is filled up with longitudinal elastic bundles. The inner layer of the propria is made of a thin fibrillar connective tissue and is rich in blood capillaries, but infiltration of lymphocytes is very slight here.

The outside of the propria is lined by a submucosa of loose connective tissue, in which are found sporadic fat tissues and tracheal glands. These glands are generally worse developed in goat than in man and are usually of mucous nature, but more rarely some serous glands are also detected. The number of the glands decrease slowly as we go more distalwards. The tracheal cartilages covered by well-formed perichondrium are hyaline, as in man as well as other auimals.

A smooth muscle layer is found along the paries membranaceus, but interestingly enough, this layer lies inside the gland layer, unlike in man, and goes on 
better developed as the trachea runs distalwards, forming a quasi-circle nearly reaching the point diametrically opposite the median of the paries membranaceus in a cross-section at the bifurcatio tracheae. Here, the tracheal glands are located between the muscle layer and the cartilages.

At the bifurcatio, the trachea branches out into the right and left extrapulmonary bronchi, which after running out a far shorter course than in man, ramify into intrapulmonary bronchial branches of ca. $8 \mathrm{~mm}$ in diameter and soon divide into numerous thinner bronchial branches that slowly lose in size. The extrapulmonary bronchi are nearly identical in structure as the distal portion of the trachea, but the intrapulmonary bronchial branches are somewhat different in histological formation.

As the more outstanding differences, we may point out that the cartilages in the intrapulmonary branches are disconnected circumferentially into several pieces, which sometimes mutually overlap and form 2 or 3 layers; the muscle layer, lining the outside of the considerably thinned-down longitudinal elastic bundle layer, forms a nearly closed circular tube (Fig. 6); the bronchial glands similar to the tracheal glands in nature are found not only between the muscularis and the pieces of cartilages, but also rather frequently in the adventitia around the cartilages; the goblet cells in the epithelium are somewhat more frequent here than in the trachea and the submucosa now contains nearly no fat tissue but in the adventita there is still much fat tissue.

In the medium branches of ca. $4 \mathrm{~mm}$ in diameter formed by ramification of the large bronchial branches, the cartilages are broken down into smaller and more numerous bits, but otherwise little change is observed in fine structure, only the parts being smaller in proportion. In the thinner bronchial branches of ca. $2 \mathrm{~mm}$

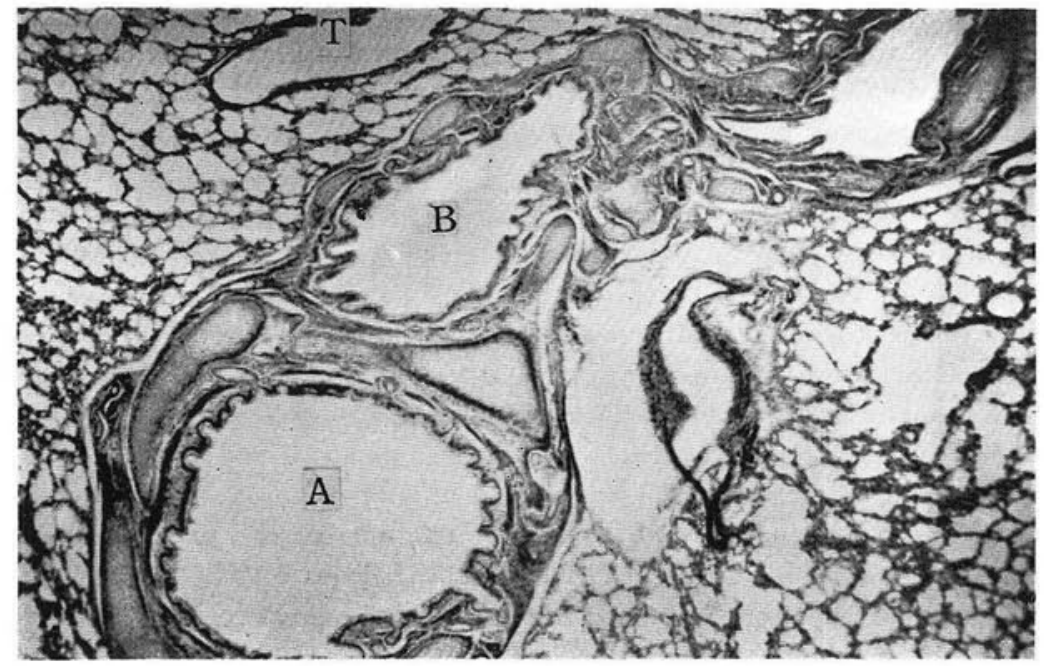

Fig. 1. Intrapulmonal bronchial ducts of a goat. $A$ bronchial branch of $2 \mathrm{~mm}$ diameter, $B$ bronchial branch of $1 \mathrm{~mm}$ diameter, $T$ bronchiolus terminalis. Details in the text. SETO's impregnation. Photo $\times 24$. 
in diameter, a weak formation of longitudinal mucous folds is observable in their mucous membrane, the cartilages consist in ever more numerous and tinier chips and the muscle layer becomes extremely thin, while the bronchial glands decrease abruptly in number, as shown in Fig. $1 \mathrm{~A}$. In the very small bronchial branches (Fig. 1B) of about $1 \mathrm{~mm}$ in diameter, the cartilaginous pieces are even further reduced in size and also in number here, so that their arrangement becomes looser and longitudinal mucous folds become prominently observable in the mucous membrane. The epithelium here is a $2-3$-rowed ciliated epithelium and the longitudinal elastic bundles are now scarcely observable. The circular muscle layer becomes

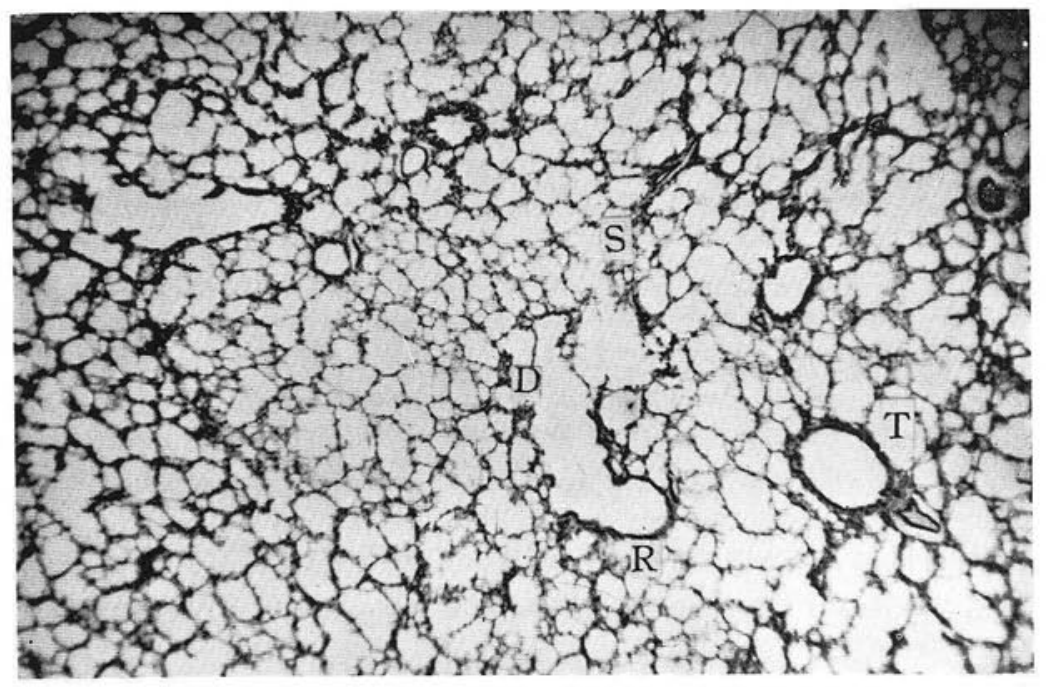

Fig. 2. Terminal parts of the bronchial branches of a goat. $T$ bronchiolus terminalis, $R$ bronchiolus respiratorius, $D$ alveolar duct, $S$ alveolar sac. Details in the text. Same staining. Photo $\times 24$.

considerably thinner and the bronchial glands are very poor in the development.

In the smallest branches of ca. $0.5 \mathrm{~mm}$ diameter formed by ramification of the above bronchial branches, the cartilaginous pieces are scarcely found, the epithelium generally consists of one layer of ciliated cells, the very thin propria is lined by a thin circular muscle layer and the adventitia outside it is composed of a rather densely arranged collagenous connective tissue. These smallest bronchial branches may be called the bronchioli terminales (Figs. 1 and 2). Further distalwards, the epithelium becomes a non-ciliated cylindrical one, the smooth muscle fibres outside it are abruptly reduced in number and the connective tissue layer further outside becomes extremely thin. These fine branches are the so-called bronchioli respiratorii. As shown in Fig. 2, some alveoli are found in the walls near the furthest ends of these bronchioli.

The brenchioli respiratorii pass over into alveolar ducts and finally end in alveolar sacs (Fig. 2), in the same manner as in man and other mammals. The alveoli are formed by nucleated cubic and unnucleated flat bright epithelial cells, 
showing distinct cellular boundaries.

There have been scarcely any reports in the past on the nerve supply of animal trachea, but a very dependable report on the subject treating the human trachea has been given out by SASAKI of this laboratory. Thus, I will given hereunder my findings on the innervation of the trachea of goat in comparison with the data reported concerning the human trachea. It is well known that the nervs supplied to the trachea are derived from the vagus and the sympatheticus. These nerve branches, while running down within the adventitia, branch out and anastomose to form plexus which is formed rather loosely in the ventral and the lateral sides but much more densely in the dorsal side of the trachea and contain some small ganglia, as was in the case of the human trachea. This plexus formation, however, is considerably poorer in the goat's than in the human trachea.

SASAKI calls this plexus the fundamental or primary plexus. In human trachea, many nerve branches run between the cartilages and through the paries membranaceus into the submucosa and form the plexus submucosus or secondary plexus. Fine nerve branches run out from this plexus further into the propria, wherein they form the plexus laminae propriae or tertiary plexus.

The above nerve plexuses observed in the human trachea are equally found in the trachea of goat, though in a far poorer development, the plexus laminae propriae being especially ill developed. These plexuses are mainly composed of nonmedullated fine vegetative fibres, but a rather large number of thick medullated sensory fibres - probably originating in the vagus - are also present.

The ganglia found in the tracheal wall are rather worse developed than the ganglia found in the intrapnlmonary bronchial branches mentioned hereunder. Since the ganglia in these two parts are of the same nature, I will not here go into details on the ganglia and the nerve colls therein. The vegetative fibres spread out in the mnscularis and the tracheal glands, to end as always in STÖHR's terminal reticula. In agreement with the numerous works at this laboratory, these teminal reticula stand in contact control over the cells of these tissues, but $I$ found them apparently not running further into the cell bodies.

I have said that sensory nerve fibres run into thr goat's trachea too and I will now answer the question how and where the terminations of these fibres are formed, citing the report on the human trachea by SASAKI in comparison.

According to SASAKI, in the human trachea, sensory terminations 'Type I concerned with the HERING's blood-pressure falling reflex and simple glomerular terminations are formed in the paries membranaceus, in particular, in its muscle tissue. In the epithelium too, a rather large number of simple and complex branched terminations are formed by thick fibres showing very marked change in their rather peculiar winding courses.

In my specimens of goat's trachea, terminations of very thick sensory fibres were similarly found in the smooth muscle layer, but fibres ending in the ciliated epithelium were observed only rarely, the sensory fibres generally ending subepithelially in the propria without forming intraepithelial terminations. The number of the sensory fibres in the goat's trachea is comparatively small.

The sensory terminations formed in the muscle tissue of the trachea of goat 
are considerably different in form from those in the human trachea, glomerular terminations and sensory terminations Type I possessing special end-plates concerned with the blood-pressure falling reflex as reported by SASAKI being found scarcely in my specimens. In the goat's trachea, the sensory terminations are represented by considerably complex branched terminations, of which the terminal fibres often run wavy or looping courses and show marked change in size, ending in sharp points.

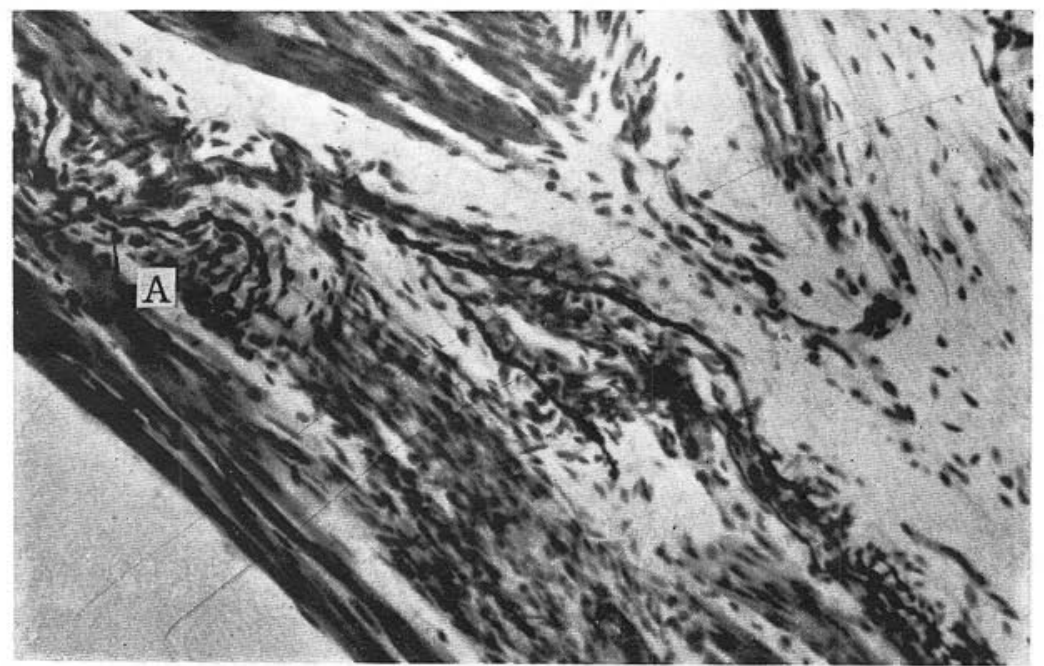

Fig. 3. 2 simple branched sensory terminations originated in a thick medullated stem fibre respectiviely formed in the circular musculature of the proximal part of the trachea of a goat. Terminal fibres consist in thick fibres showing conspicuous change in size. Details in the text. Same staining. Photo $\times 200$.

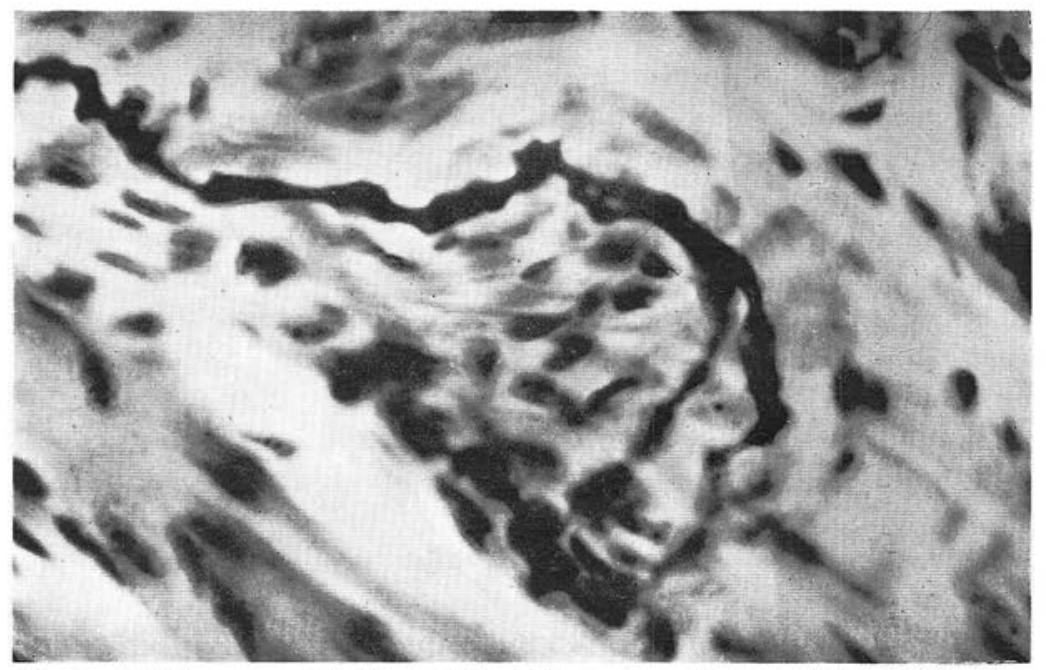

Fig. 4. A higher magnification of Fig. $3 A$, to show the powerfulnes of the stem fibre and its branches. Photo $\times 800$. 
In Fig. 3 are shown 2 simple sensory branched terminations formed by 2 thick sensory fibres. Fig. 4 shows the terminal area (A) in Fig. 3 in higher magnification, showing how prominent a change in size is shown by the very stout stem fibre and its branches.

Fig. 5 illustrates a comparatively simple branched termination perhaps formed by a single thick medullated sensory fibre in the circular muscle layer lining the inside of the paries membranaceus. Its terminal fibres here too show marked change in size and end sharply, while their courses are not much winding but are compara-

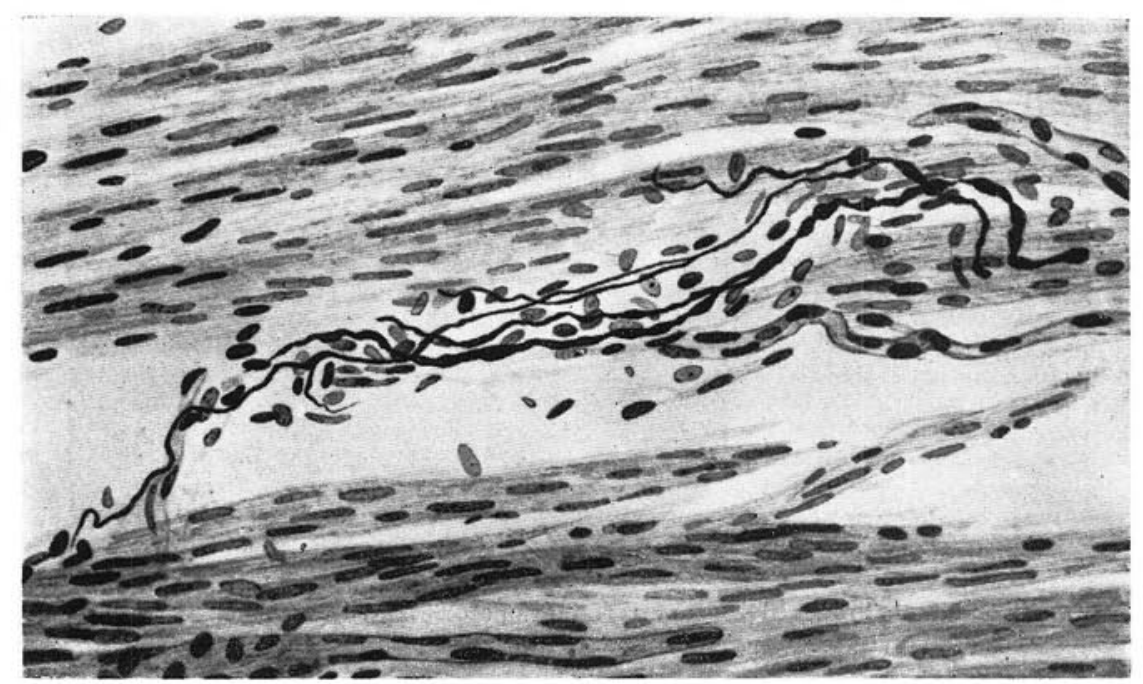

Fig. 5. A branched sensory termination found in the circular muscle layer in the proximal part of the trachea of a goat. Terminal fibres show marked change in size.

Same staining. $\times 320$.

tively straight. In Fig. 6 is shown a branched termination also found in the smooth muscle layer on the inside of the paries membranaceus and formed much more complex than the former. Here, a thick medullated fibre, after losing its myelin sheath, divide into 3 branches, which pass over again into 2 or 3 terminal fibres each ending in sharp points. The terminal fibres run rather markedly winding courses but show not much change in size.

Thus, in the goat's trachea, very prominent branched sensory terminations are found in the muscle tissue of the paries membranaceus, quite as in the human trachea. These terminations in the goat's trachea, however, never show glomerular arrangement or form end plates, but the nature of the terminal fibres is similar to that in man, very thick and markedly changing in size. Such similarity in form leads to the suspicion that among the complex branched terminations in the goat's trachea there are some sensory terminations more or less resembling those concerned with the blood-pressure falling reflex in nature.

The sensory fibres running into the propria of the human trachea consist mainly in thick fibres and most frequently enter further up into the epithelium to end in branched type intraepithelial fibres. In the goat's trachea, however, the sensory 


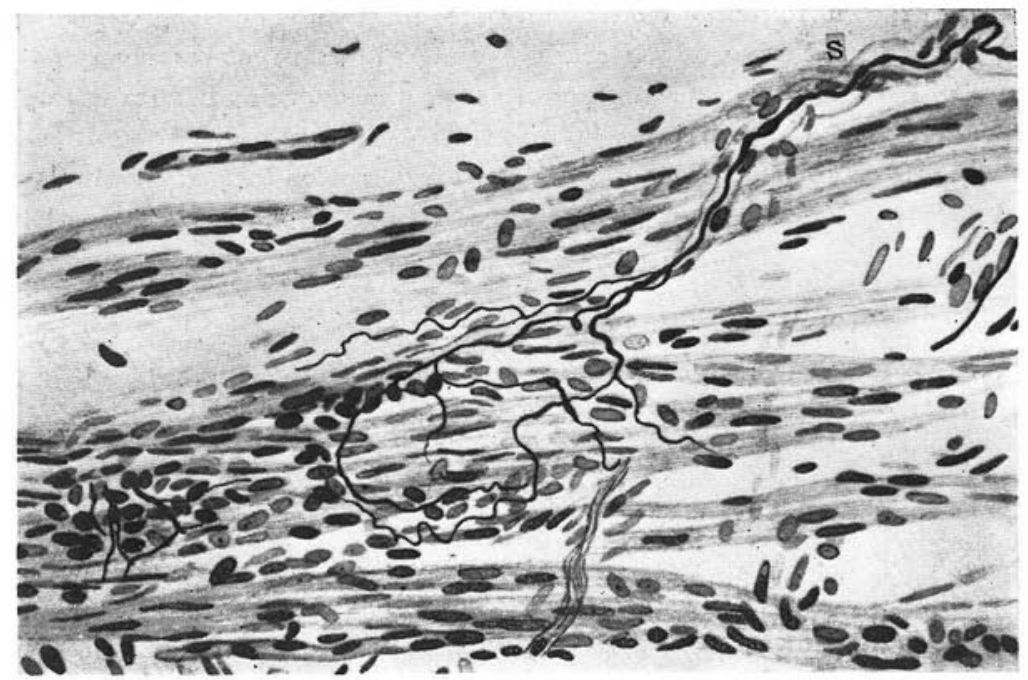

Fig. 6. A complex branched sensory termination found in the circular muscle layer in the distal part of the trachea of a goat. $s$ conspicuous medullated sensory stem fibre. Details in the text. Same staining. $\times 320$.

fibres in its propria are much smaller both in number and size than in the human trachea, end usually in simple branched terminations subepithelially, only very few of them entering the epithelium. Even these few intraepithelial fibres run only a very short way into the very basal layer of the ciliated epithelium.

Fig. 7 shows a simple branched sensory termination found in the propria in the proximal part of the goat's trachea. The stem fibre, demyelinated upon entering

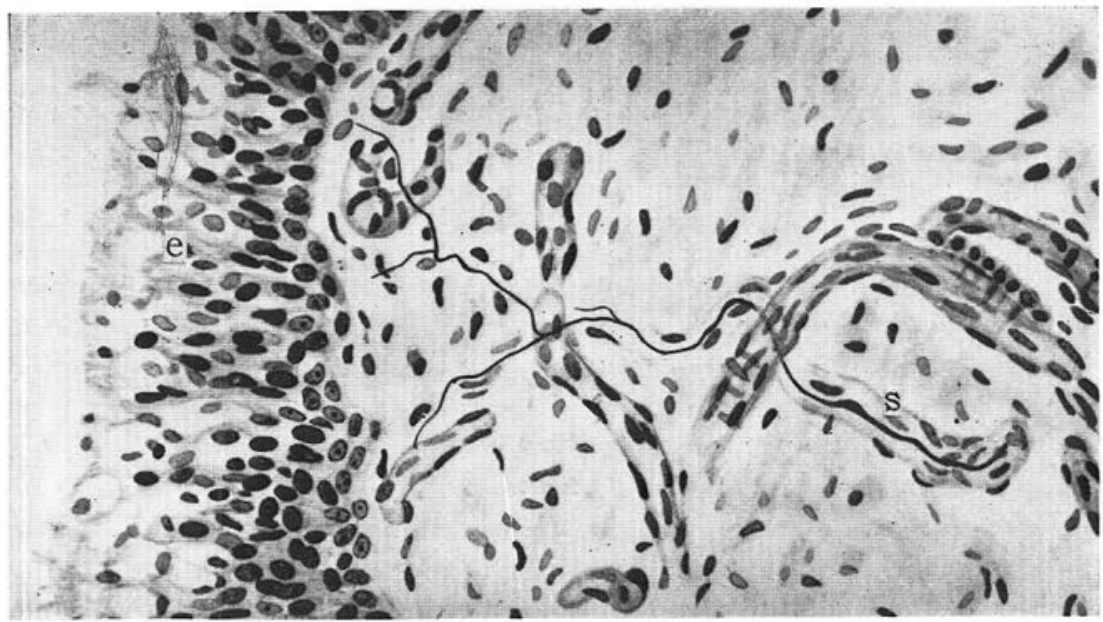

Fig. 7. A simple branched sensory termination formed subepithelially in the proximal part of the trachea of a goat. $e 5-6$-rowed ciliated epithelium containing goblet cells, $s$ thick medullated stem fibre passing through the longitudinal elastic bundle layer. Details in the text. Same staining. $\times 320$. 
the subepithelial loose connective tissue layer from the layer of longitudinal elastic bundles, soon branches out into 4 terminal rami, which are comparatively fine and unchanging in size and end in sharp points. some of the terminal fibres run up close to the underside of but not further up into the epithelium.

In Fig. 8 we see another simple branched termination formed by similar fine terminal fibres, found in the propria of the distal part of the trachea. Its terminal

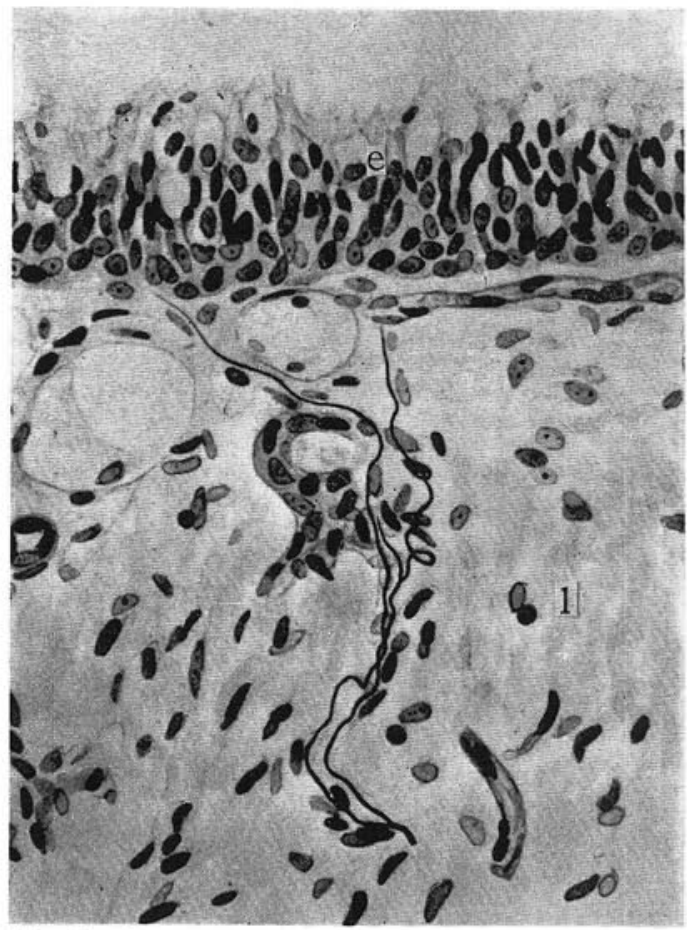

Fig. 8. Ditto. e ciliated epithelium, 1 longitudinal elastic bundle layer. Details in the text. Same staining. $\times 320$.

fibres reach close up to the epithelium without penetrating into it. The rather fine single medullated stem fibre forming the termination shown in Fig. 9 found in the distal part of the trachea, after losing its myelin sheath upon entering the subepithelial loose connective tissue, runs epithelialwards and penetrates very short way into the epithelium before ending sharply. Such intraepithelial fibres, however, are only very rare in the goat's trachea.

Plexus pulmonales ant. et post. are formed also in the adventitia of bronchus of goat too. These fibres run through the hilus of the lung along the major bronchial branches into the lung, as do those in man and other mammals. The nerve bundles forming these plexuses are far worse developed than the same in man (HAYASHI) and considerably poorer than those in $\operatorname{dog}$ (SAITO), but are far more powerful than in bat (NUMATA). 
The nerve elements forming these plexuses are derived from the sympathicus and the parasympathicus of the $n$. vagus, and comprise not a small number of sensory fibres coming from the vagus. Groups of ganglion cells or ganglia are found in formation here and there in connection with the fundamental or primary plexus. Some major ganglia contain about 30 nerve cells in one cross-section (Fig. 10). But this number amounts to a mere onethird or one-half of the number of the nerve cells in large ganglia in man or dog, but is much larger than the same in bat.

In the submucosa and the propria of the bronchus and the large bronchial branches as in the trachea, we find plexus submucosus or secondary plexus and plexus laminae propriae or tertiary plexus. These are also very poorly developed as those in the trachea described above.

The above arrangement of the plexuses formed in the major bronchial branches stands unchanged in the smaller bronchial branches too, but their develop-

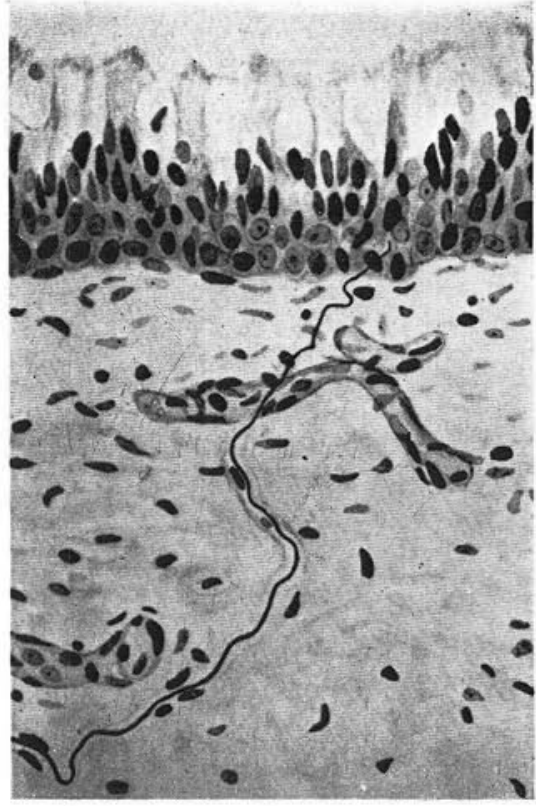

Fig. 9. An unbranched intraepithelial fibre originated in a comparatively thin medullated sensory fibre found in the mucous membrane in the distal part of the trachea of a goat. Same staining. $\times 320$. ment becomes poorer in proportion to the reduced diameter of the branches, the

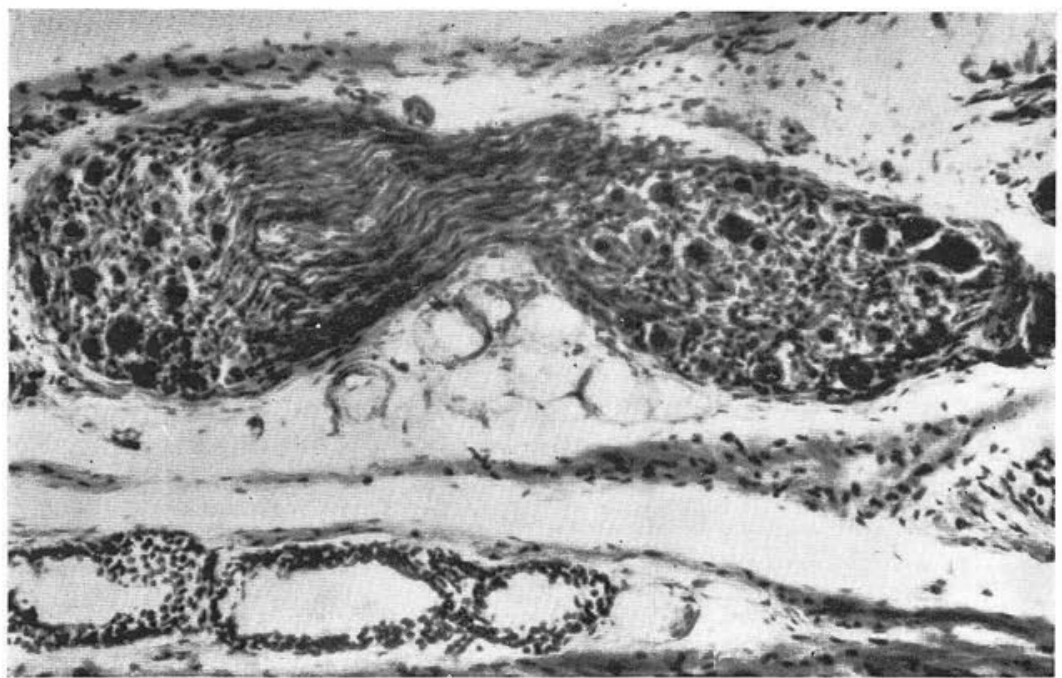

Fig. 10. 2 large ganglia in the primary plexus in the adventitia of the large bronchial branch of a goat. Same staining. Photo $\times 140$. 
nerve bundles as well as the ganglia gradually losing in size. It is, however, of high interest that even in the walls of the terminal bronchioli, groups of a few nerve cells are still not rarely observed.

The nerve cells in these ganglia, quite as in the human and the canine lunos, have each plural nerve processes, showing unmistakable multipolarity and their sympathetic nature. Both DOGIEL's Type I and Type II cells as classified by the arrangement of the nerve processes are represented here in the lung of goat, but as observable in Fig. 11, most of these cells belong to the Type II, Type I cells being

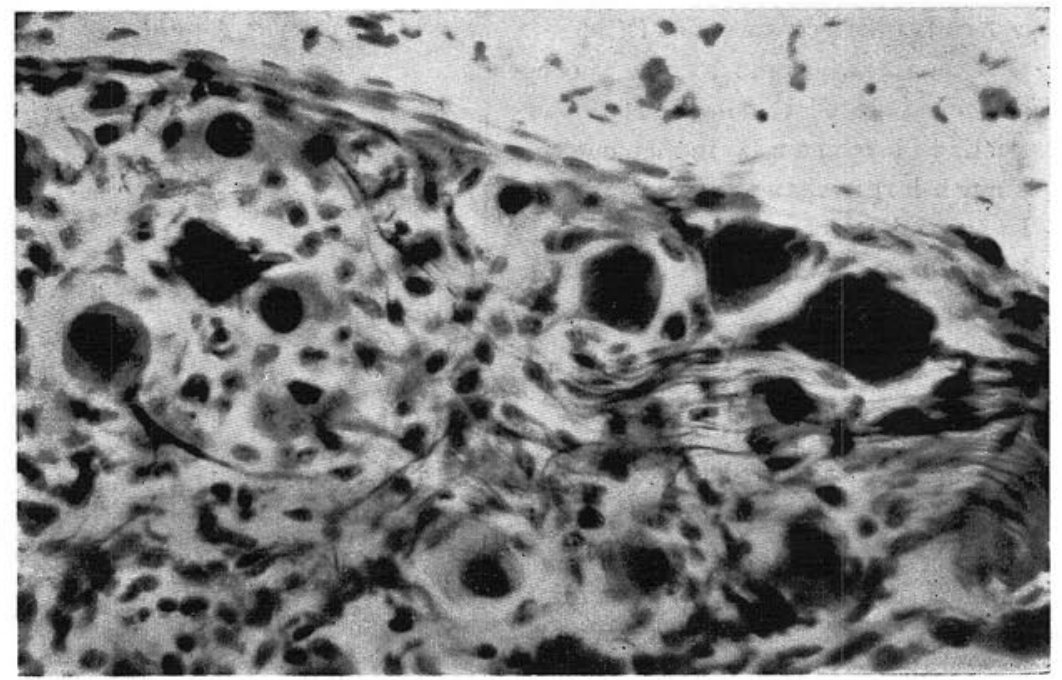

Fig. 11. Higher magnification of the ganglion in the right hand of Fig. 10. All the ganglion cells show the specific multipolarity of sympathetic nature (DOGIEL's Type II cells). Photo $\times 400$.

extremely scarce. The numerical proportion of the Type I and Type II cells is seemingly not only unequal by different organs, but also by species and individuals of animals. For example, Type II cells are much more numerous in the lungs of man and dog (HAYASHI), but SAITO says that the number of Type I cells is larger than that of Type II cells in the canine lung. More recently, SATO has reported on the relative frequency of the cells of the two types in the human sympathetic trunk ganglia, and his finding was contrary to the result reported by HERMAN. The above discrepant findings seem to indicate that the cells of both the types are of the same nature functionally though somewhat different morphologically. Therefore, the numerical proportion is not much worthy of attention, as long as we are concerned with the function of the cells. The vegetative fibres are distributed in the bronchi and the intrapulmonary bronchial branches just in the same manner as in the trachea above, always ending in STÖHR's terminal reticula in these parts as well.

Next, I will make some documentary review of reports on the distribution of sensory fibres in the bronchus and the large bronchial branches. SUNDER-PLASS- 
MANN and HAYASHI have respectively demonstrated that, in the muscle layer of the major bronchial branches of man, there are some sensory terminations Type I concerned with the blood-pressure falling reflex and similar terminations, like those found by SASAKI in the human trachea. In dog also, branched terminations of similar nature but simpler in construction have been discovered in the muscle layer of the same site (SAITO). In man, rather complex branched terminations are found in the ciliated epithelium of the mucous membrane here (HAYASHI). In dog, some intraepithelial fibres are indeed observable in this part, but these are very small in number and are usually of the unbranched type, almost all the sensory fibres terminating subepithelially, these being also small in quantity and of unbranched and simple branched types only. In bat (NUMATA), however, beside the terminations resembling the Type I blood-pressure falling reflex terminations found in the muscle layer of the major bronchial branches, rather complex branched terminations are also formed in their propria as well as in their epithelium. In short, the development of the sensory terminations here is of course the highest in man and next in bat, a dog standing below a bat in this respect - a very interesting finding indeed.

The sensory innervation of the bronchus and the bronchial branches of more than medium size of goat is similar to that of the trachea above in outline but somewhat poorer in development. First, in the muscle layer here, as in the trachea, branched terminations originating in very thick myelinated fibres (Fig. 12) were observed. These terminations are of the same nature as those in the trachea, being only simpler in formation than the latter. Since in dog, such terminations in the corresponding part show of ten more intricate ramifications and neurofibrillar ex-

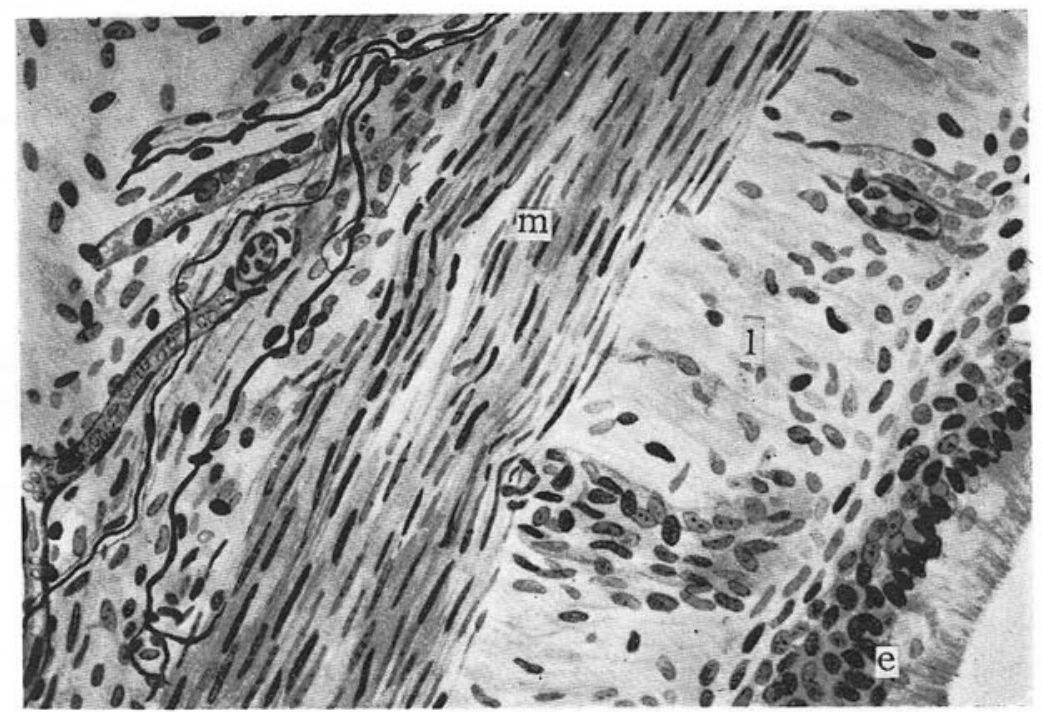

Fig. 12. A simple branched sensory termination formed in the circular muscle layer $(m)$ in the large bronchial branch of a goat. $e$ ciliated epithelium, 1 longitudinal elastic bundle layer. Same staining. $\times 320$, reduced to $4 / 5$. 
pansions in the courses of the terminal fibres, the intramuscular terminations in the bronchus and the major bronchial branches of geat may be deemed somewhat worse developed than those in dog.

Unbranched and simple branched sensory terminations are found in the propria mucosae of these parts too, but these are also a little poorer in development than those in the tracheal propria. Here, scarcely any end in intraepithelial fibres. These terminations are always formed by thin myelinated fibres as those in the

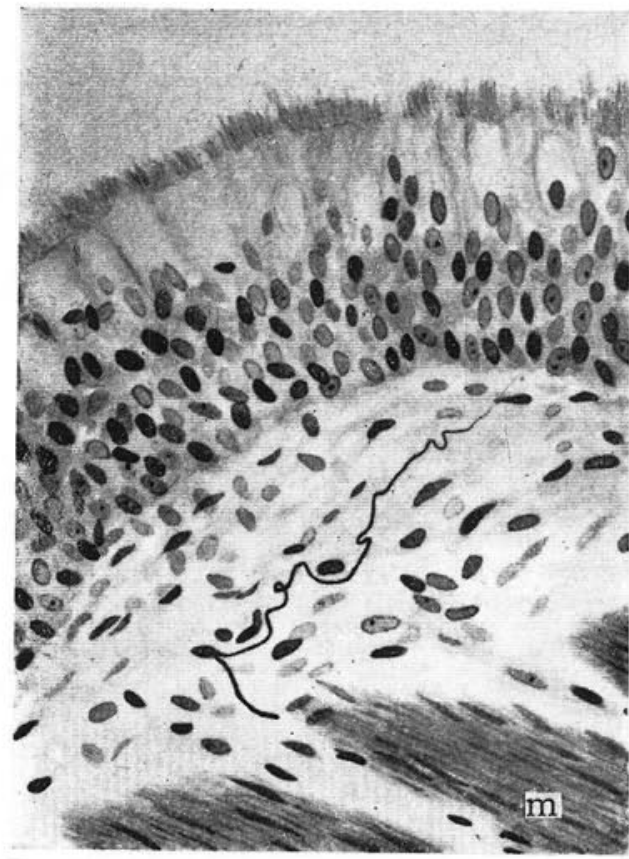

Fig. 13. An unbranched sensory termination ending sharply direct beneath the epithelium found in a large bronchial branch of a goat. $m$ muscularis. Same staining. $\times 320$. trachea. In Fig. 13 is shown an unbranched sensory fibre originating in a thin myelinated fibre found in the propria of an intrapulmonary bronchial branch of 8 $\mathrm{mm}$ diameter. It ends sharply just beneath the epithelium and does not run further into the epithelium.

The above findings reveal that in the development of the sensory terminations in the major bronchial branches, a goat stands far below man and even below a bat and a dog.

The existence of sensory fibres and their terminations in the minor bronchial branches and bronchioli was demonstrated by SAITO and NUMATA of the laboratory in the lungs of dog and bat respectively. It is of interest that in dog, the branched terminations in the small bronchial branches are sometimes rather more complex than those in the larger bronchial branches and their terminal fibres frequently penetrate into the epithelium. Besides, in the canine bronchioli, some simple glomerular terminations and unbranched terminations reaching close up to the epithelium have been also found. Thus, in dog, more complex-formed sensory terminations are found in these minor bronchial ducts than those observable in the major ones.

In the lung of bat, conspicuous intraepithelial fibres are rather often found in the smaller bronchial ducts. It is of interest that sensory terminations have been observed in the interalveolar septa too. These sensory terminations in the smaller bronchial ducts of bat, however, are far simpler in formation than those in dog. Thus, in the lung of bat, the sensory terminations in the major bronchial branches are far more complex than those in the minor bronchial branches and the bronchioli, quite contrary to what was said above concerning the canine lung. 
Now, in my goat's specimens, the sensory fibres and their terminations are apparently somewhat better developed in the minor than in the major bronchial ducts, somewhat resembling the case in dog. Sensory fibres are found rather frequently here and rather thick fibres at that, with rather complex-formed terminations. But the complexity is limited to the order of 2 or 3 branch formation, and of course unbranched terminations are also not at all rare either.

Fig. 14 shows a thick and a thinner sensory fibres found subepithelially in a

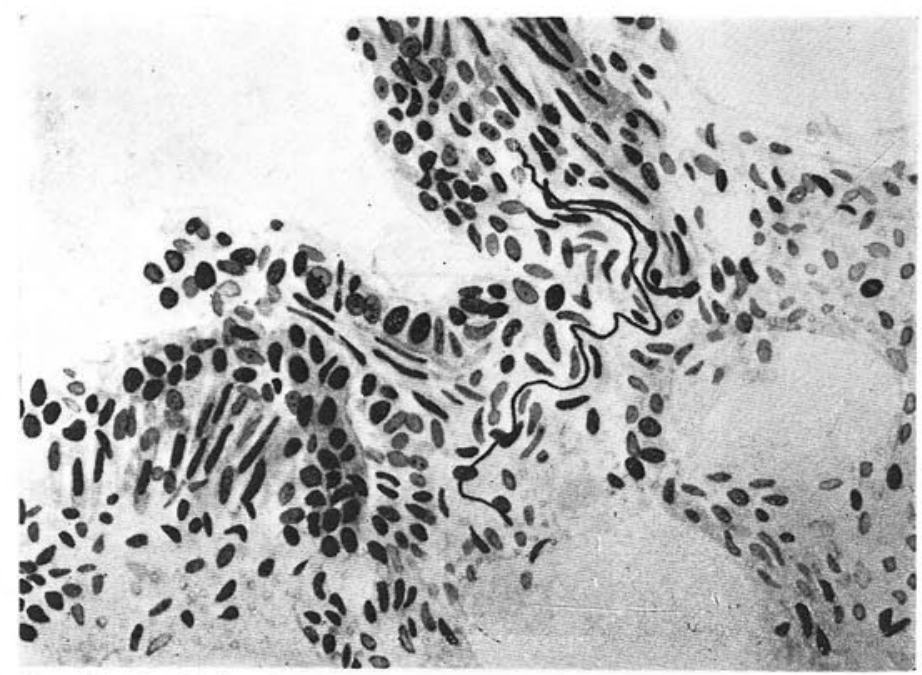

Fig. 14. A thick and a thinner sensory fibres running along a bronchiolus terminalis of a goat. Same staining. $\times 320$.

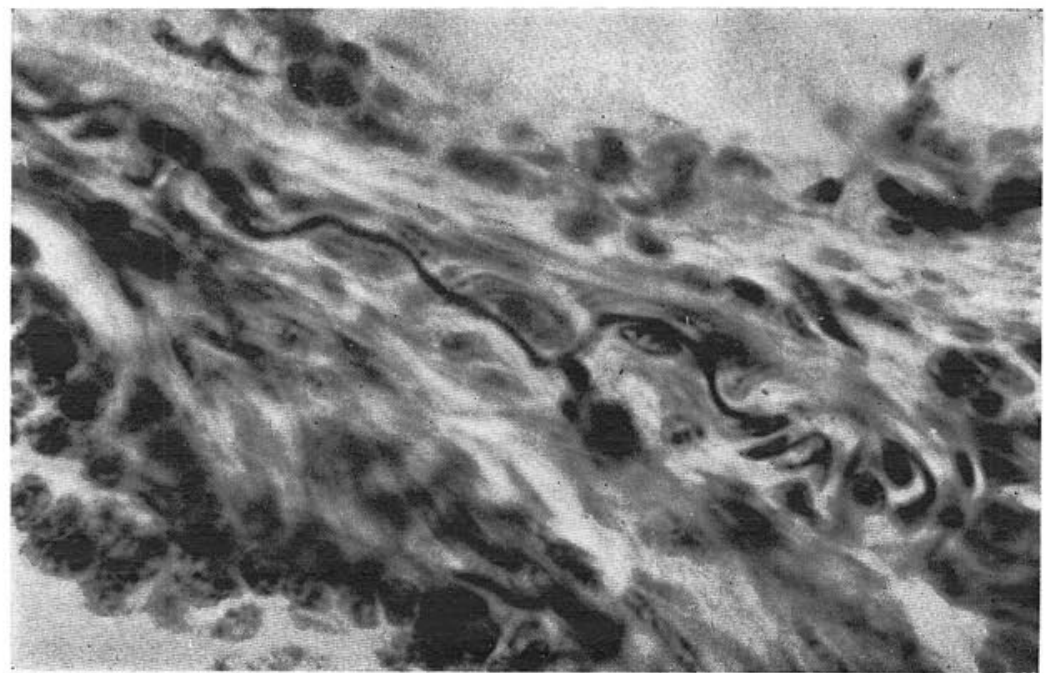

Fig. 15. A very thick sensory fibre running through the connective tissue layer in the wall of a bronchiolus terminalis of a goat. Same staining. Photo $\times 800$. 
bronchiolus terminalis. Since both these fibres are cut at both ends, we cannot see how these fibres terminate. But this figure proves at least that such thick sensory fibres are present in the vicinity of the small bronchial ducts, too. Fig. 15 shows a microphotograph of a thick sensory fibre found in the same site.

In Fig. 16, we see a thick myelinated fibre coming into the connective tissue layer of the bronchiolus respiratius representing the submucosa here, branching into a long and a short terminal branches after losing its myelin sheath and ending sharply. This termiuation is in the form of bifurcated type.

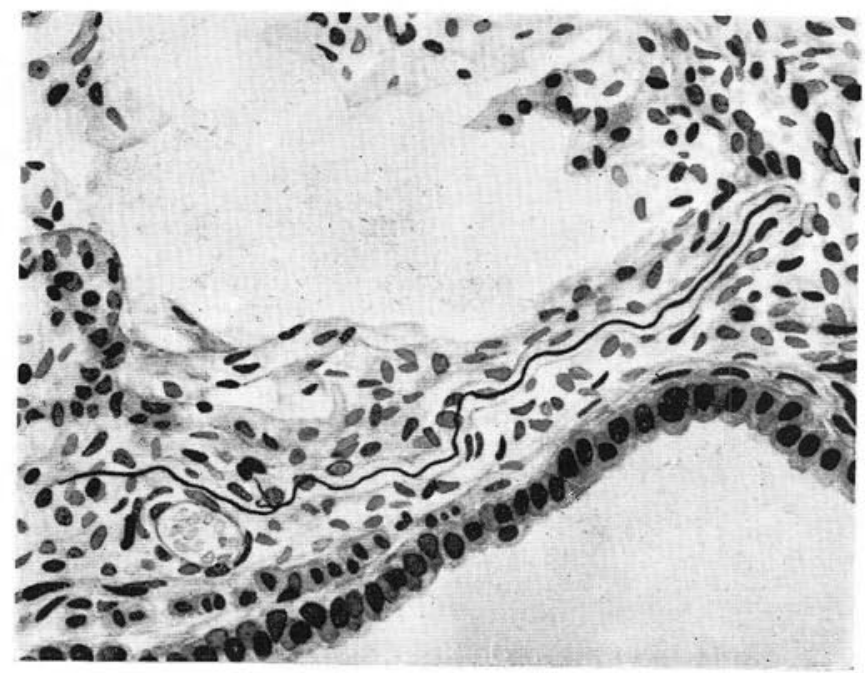

Fig. 16. A sensory termination of bifurcated type originated in a conspicuous medullated stem fibre found in the connective tissue layer around a bronchiolus respiratorius of a goat. Same staining. $\times 320$.

In the lung of goat, to our high interest, we found a rather large number of thick sensory fibres running into the interalveolar septa and ending there in unbranched or simple branched terminations. In this respect, the situation is somewhat resembling the case of bat's lung, but since in the latter, the terminations are usually nothing but unbranched terminations, the terminations here may be said to be somewhat more complex in the goat's interalveolar septa. In Figs. 17 and 18 are illustrated an unbranched and a simple branched terminations found in the interalveolar connective tissue septa of the luug of goat, respectively, both rather stout terminations. It is not yet known whether their terminal fibres run into the epithelial cells of the alveolar walls, but it seems a part of them enter the cells.

In the interlobular connective tissue of the lung of goat were very frequently found nerve bundles containing a rather large number of thick medullated fibres and running in company with the small pulmonary veins (Fig. 19). These nerve bundles run through the connective tissue up to the visceral pleura forming the surface of the lung and then branch out into finer bundlets in the connective tissue layer there. NUMATA has also observed thick sensory fibres running into the 


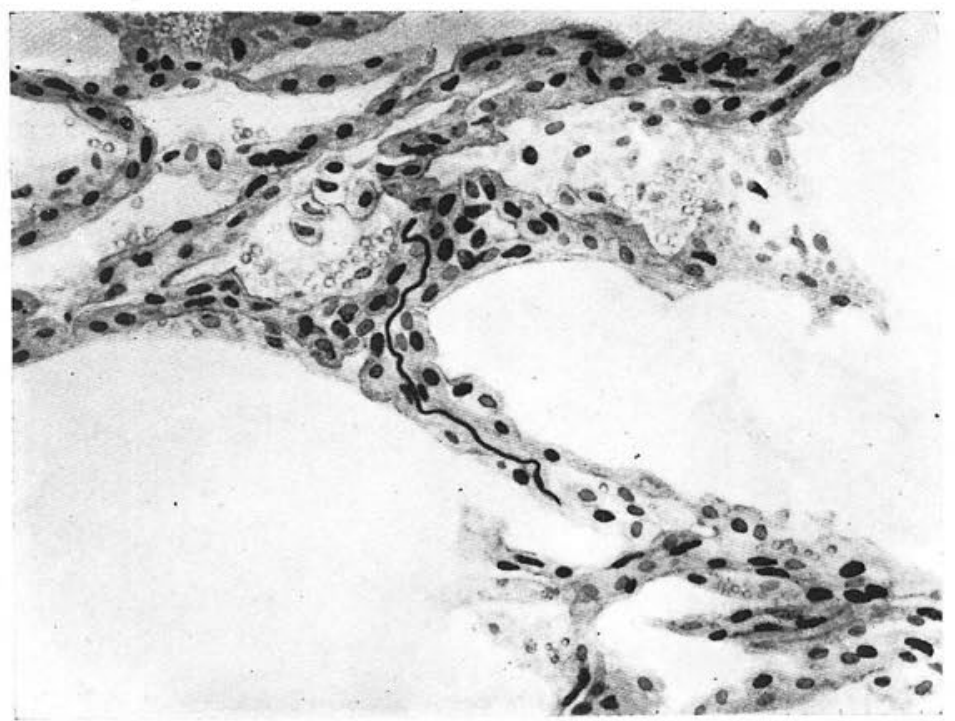

Fig. 17. An unbranched sensory termination found in the interalveolar connective tissue septum of the lung of a goat. Same staining. $\times 32$.

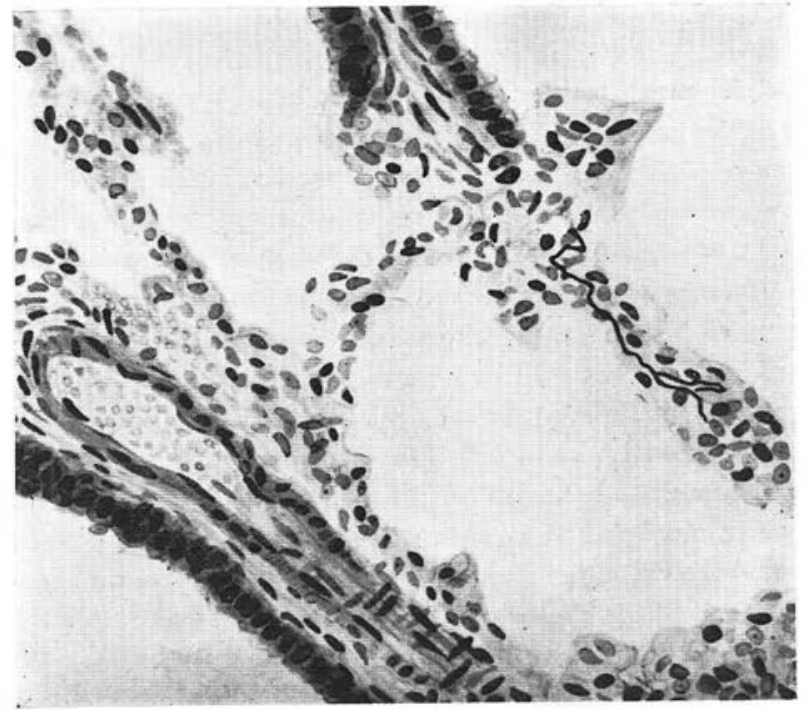

Fig. 18. A bifurcated sensory termination found in the interalveolar connective tissue septum of the lung of a goat. Details in the text. Same staining. $\times 320$, reduced to $3 / 4$.

pleura vissceralis of bat and reports that these end always in unbranched terminations. In my study of goat's lung, I failed to ascertain the terminal mode of these fibres here, but I suppose they end similarly in unbranched, or may be, in simple branched terminations. 


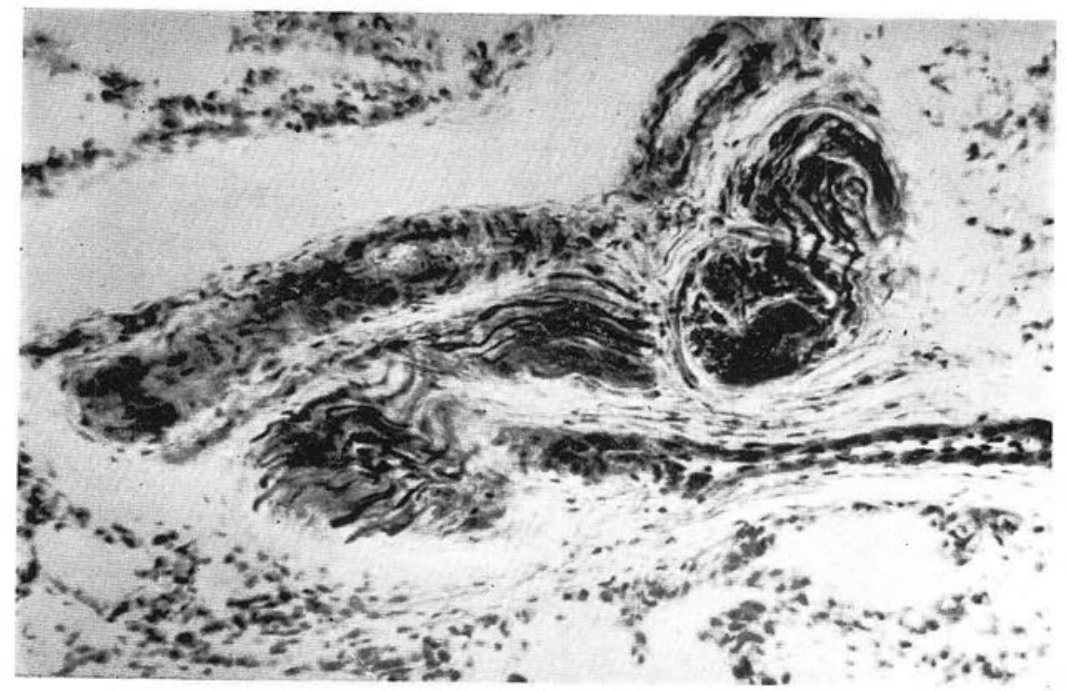

Fig. 19. Rather stout nerve bundles containing many thick sensory fibres running in the interlobular connective tissue of the lung of a goat. Details in the text. Same staining. Photo $\times 200$.

\section{Summary.}

A few specially mentionable findings on the histology of the respiratory tract of goat are given in the following:

In the trachea, a circular smooth muscle layer lies inside of the tracheal glands, in the portion where the paries membranaceus is formed. This muscle layer becomes better developed distalwards and in the distal end part, comes to cover the nearly complete circumference of the trachea outside its mucous membrane. The right and left extrapulmonary bronchi, very short ducts soon replaced by large intrapulmonary bronchial branches, have a fine structure similar to that of the distal end of the trachea, except that the cartilages are circularly divided into many pieces and are arranged intermittently or in 2 or 3 layers.

In the small bronchial branches ca. $2 \mathrm{~mm}$ in diameter, the cartilaginous pieces are reduced both in number and in size, so weak longitudinal mucous folds come into formation and the bronchial glands also decrease abruptly. In the smaller bronchial branches ca. $1 \mathrm{~mm}$ in diameter, more prominent longitudinal mucous folds are formed and the epithelinm becomes a $2-3$-rowed ciliated one, but the muscle layer is yet perceptibly developed. In the bronchioli terminales, the epithelium is composed of one layer of ciliated cells and outside the propria, a circular muscle layer is still visible. The bronchioli respiratorii are lined by a one-rowed nonciliated cylindrical epithelium and a small quantity of muscle tissue. Nothing mentionworthy was found in the alveolar ducts or the alveolar sacs.

As in the human trachea (HAYASHI), sensory fibres and their terminations derived from the $\mathrm{n}$. vagus are found in the trachea of goat too, but in the latter, their number and size are smaller than in man. The thick medullated sensory fibres 
end in branced terminations in the muscle layer, but never forming end-plates as seen in man. Their form, however, suggests the possibility that they are so many Type I terminations concerned with the reflex of lowering the blood pressure. The thin medullated fibres run into the propria and end subepithelially in unbranched and simple branched terminations, only a very few running further into the epithelium. In goat's trachea, no such branched intraepithelial terminations as found in the human counterpart were ever found.

As in man and other mammals, in goat too, primary, secondary and tertiary plexus are formed in the interpulmonary bronchial branches, though somewhat poorer in development. In the muscle layer are found branched terminations originating in thick myelinated fibres, while in the propria mucosae are seen some unbranched and simple branched terminations formed by thin myelinated fibres. No intraepithelial fibres are found here. The above findings are rather similar to those obtained in dog (SAITO), but the terminations are somewhat poorer in development than those in dog's bronchus and major bronchial branches.

Sensory fibres and their terminations are found in the small bronchial branches and even in the bronchioli of goat too, as it was the case with $\operatorname{dog}$ (SAITO) and bat (NUMATA). As in dog, these are better developed than in the larger bronchial branches. The sensory fibres are rather large both in number and in size and simple branched terminations are also found here and there, beside the unbranched ones.

What is of interest, unbranched and simple branched terminations formed by rather thick medullated fibres are found also in the interalveolar septa of goat, as in those of bat, in a somewhat better development than in the latter.

In the interlobular connective tissue of the lung of goat, nerve bundles containing many thick medullated fibres are found running in company with small pulmonary veins. These bundles run further to reach finally the pleura visceralis. The sensory fibres, as in bat, probably end in unbranched or simple branched terminations in the pleura, but $I$ regret $I$ failed in adequately ascertaining their terminal mode.

\section{内容自抄。}

山羊の文管始部の膜様部で気管腺の内力に桷走の平滑筋唐が見られるが，之は 造位方に向って発達良好となり，気管末端部では粘膜沽有償の周国を完全飞包囲 与るに至る，左右肺外気管支は甚た短い経過の後，肺内大気管支枝に移行するが， 己等気道の微組構造は前の気管末端部の場合に略ぼ一致する。

経約 $2 \mathrm{~mm}$ の中等大気管支枝で軟骨片の数は減少, 徒って軽度の縦走性粘膜 旇壁の形成を見，又気管支腺も急激な減少を示す，経約 $1 \mathrm{~mm}$ の小気管支枝では 皱譬は著明，上皮は 2 列性顫毛上皮となる。終末性細気管支は 1 列性顫毛上皮， 狭い固有膜及び弱、筋層とから成り，呼吸性紐気管支は 1 列性円柱上皮と僅少の 平滑笳線維となら成る，肺胞管及び肺胞囊には特記事項は見られない。

山羊気管にる人の場合と同様，迷走神経所属と考えられる知覚線維と其終末と が証明される。但しその量もその規模も人に於けるよりは劣勢。太态い知覚線維は 
專ら筋層内に特有な分岐性終末として終り，細い線維は固有膜内に入り，上皮下 飞非分岐性及び単純性分岐性終末に終り, 上皮内線維に移行する事は甚だ稀であ る。

肺内気管支枝には人や他動物に於ける様に第 I, 第 II 及び第 III 神経對の形成 を見るが，その発達は人や犬の場合よりは劣勢である。第 I 神経叢内の神経細胞 は概ね Dogiel 氏第II型細胞で表わされる。

気管支及び大気管支枝にも知覚線維及びその終末を見るが，その終末は気管に 於ける場合に類似する，但し多少劣勢な発達を示す，尚括ここでも上皮内線維は 証明されない。

小気管支枝更に細第管支にも犬や蝙蝠の場合と同様知覚線維とその終末が発見 される. 且つ犬の場合と同様之等は大気管支枝に於けるょりる良好な発達を示寸。 即ち知覚楾維柱可成り多数に存し且つ可なり太い線維で表わされ，そして単純性 分岐性終末も所々飞発見される。

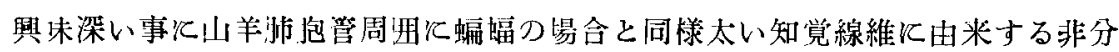
岐生及び単純生分岐沚終末が証明される。そして之は蝙蝠の埸合よりもより良好 な発達を示す。

小葉間結合織内反可なり多数の太い知覚線維を含む小神経束の走るを見る。 之 は前進して胸膜に達する，但しその知覚終末を胸摸内に発見する事が出来なかっ たが, 恐らく蝙蝠に於ける椂飞胸膜内飞単純な終末形成をなするのと教えられる。

\section{References.}

Glaser, W.: Die Nerven in der Bronchialwand. Z. Anat. 83 (1927). - Hayashi, S.: Mikroskopische Studien zur Innervation der Lunge. J. orient. Med. 27 (1937). - Larsell, O.: The ganglia, plexuses and nerve terminations of the mammalian lung and pleura pulmonalis. J. comp, neur. 35 (1922-23). - Larsell a. Dow : The innervation of the human lung. Amer. J. anat. 52 (1933) : - Loffredo, C. : Ricerche istologiche comparative sulle espansioni nervose sensitive della trachea e dei bronchi. Boll. Soc. ital. biol. sperim. 26 (1650). - Magnenat, P.: Etude neurohistologique du puomon. Acta anat. 13 (1951). Mizukoshi, T.: Histological studies on innervation of lung of human embryo. Tohokn $\mathfrak{J}$. exp. Med. 58 (1953). - Numata, T.: Histology and innervatinn of lung in bat. Arch. hist. jap. 9 (1956). - Saito, M. : Supplement to the observations on the innervation of lung in dog. Arch. hist. jap. 9 (1955). - Sasaki, Y.: Microscopic observations on the innervation of human larynx. Tohoku Igaku Zassi. 32 (1943). - On innervation of human trachea. Tohoku Igaku Zassi. 32 (1943). - Stöhr, Ph.: Mikroskopische Anatomie des vegetativen Nervensystems. Berlin, J. Springer, 1928. - Möllendorffs Handbuch der mikroskopischen Anatomie des Menschen. Rd. 4. Nervensystem. TI. 5. Mikroskopische Anatomie des vegetativen Nervensystems. Ergänzung zu Bd. 4, Tl. 1. J. Sprinerg, 1957. Sunder-Plassmann, P.: Über nervöse Rezeptorenfelder in der intrapulmonalen Bronchien des Menschen usw. Dtsch. Z. Chir. 240 (1933). - Yagita, M.: A histological study of sensory nerves in the lung and the visceral pleura. Arch. jap. Chir. 23 (1954). 